\title{
Secretory IgA adsorption and oral streptococcal adhesion to human enamel and artificial solid substrata with various surface free energies
}

\author{
INA H. PRATT-TERPSTRA, ${ }^{1}$ JAN MULDER, ${ }^{2}$ ANTON H. WEERKAMP, ${ }^{3}$ \\ JAN FEIJEN ${ }^{4}$ and HENK J. BUSSCHER ${ }^{1}, *$ \\ ${ }^{1}$ Laboratory for Materia Technica, University of Groningen, Antonius Deusinglaan 1, $9713 \mathrm{AV}$ \\ Groningen, The Netherlands \\ ${ }^{2}$ Laboratory for Public Health, Jelsumerstraat 6, 8917 EZ Leeuwarden, The Netherlands \\ ${ }^{3}$ NIZO, Postbus 20, 6710 BA Ede, The Netherlands \\ ${ }^{4}$ Department of Chemical Technology, University of Twente, P.O. Box 217, 7500 AE Enschede, The \\ Netherlands
}

Received 24 July 1990; accepted 8 August 1990

\begin{abstract}
In this paper, secretory IgA adsorption from a single component sIgA solution and from human whole saliva onto human enamel and artificial solid substrata with various surface free energies was studied as a function of time. ELISA indicated that screening or displacement of adsorbed sIgA by other salivary proteins occurred only on low surface free energy substrata, not on high surface free energy substrata such as enamel. In addition, the adhesion of three oral streptococcal strains (Streptococcus mitis BMS, S. sanguis 12 , and $S$. mutans NS), also having widely different surface free energies, to sIgAcoated surfaces was studied. The adhesion of all three streptococcal strains was significantly reduced in the presence of a sIgA coating.

However, ranking the adhesion data with respect to the various substrata revealed a similar order to that in the case of uncoated substrata, indicating that substratum properties were at least partly transferred by the adsorbed protein film to the interface with adhering micro-organisms. For $S$. sanguis 12 and $S$. mitis BMS, adhesion decreased proportionally with the amounts of SIgA detected by ELISA, but for $S$. mutans NS such relations with the amounts of SIgA detected on the protein-coated substrata were not found. Thus, for $S$. mutans NS a specific antibody effect seems to exist in addition to a non-specific protein effect like that observed for S. sanguis 12 and $S$. mitis BMS.
\end{abstract}

Key words: sIgA adsorption; oral streptococcal adhesion; surface free energies.

\section{INTRODUCTION}

The first event when foreign surfaces are exposed to a biological environment is the adsorption of proteins at the solid-liquid interface. In a later stage, bacteria and cells can adhere to this adsorbed protein layer which may lead to the formation of, for example, thrombi or dental plaque. The adsorption of proteins on foreign surfaces depends on the properties of the solid surface (e.g. zeta potential or surface free energy) and on the composition of the protein solution as, for example, serum, plasma, or saliva. Preferential adsorption of competing proteins from plasma onto the walls of artificial blood vessels is of well-known crucial importance for the formation of thrombi. [1-3].

Like plasma, saliva is a complex body fluid consisting of over 60 protein components, amongst which albumin, secretory immunoglobulin A (sIgA), $a$-amylase, 
and mucins are the main proteins identified. [4]. Selective adsorption of competing proteins from saliva onto enamel plays a key role in the formation of dental plaque, which can initiate dental caries and periodontal diseases, particularly since clean enamel is covered within minutes by a proteinaceous layer called the 'pellicle' [5]. However, the formation of a matured pellicle takes at least $2 \mathrm{~h}$ [6]. Albumin, phosphoproteins, lysozyme, sIgA, and mucins have been identified as the main salivary pellicle components [7]. The relative abundance of these proteins in the pellicle changes in time, therewith contributing to the ripening of the pellicle $[6,8$, 9].

Since the adsorbed protein layer governs to a large extent the adhesion of oral bacteria to dental enamel [10], time-dependent changes in the pellicle composition will also affect the interactions between surface components of oral microorganisms and macromolecules comprising the pellicle.

Studies of Kilian et al. [11] have shown that pellicle-bound sIgA can interfere with the adhesion of oral streptococci by two separate mechanisms, which are related to the protein effect and the inherent specific antibody effect, respectively. An SIgA coating of hydroxyapatite contributed positively to the adherence of two Streptococcus sanguis strains and negatively to the adherence of $S$. mitior and $S$. mutans as compared with the adherence to uncoated hydroxyapatite. For $S$. mutans this could be attributed mainly to a non-specific protein effect, while for $S$. sanguis and $S$. mitior this could be attributed to both a non-specific protein effect and an inherent specific antibody effect.

Recently we have demonstrated that streptococcal adhesion to an 'early' pellicle (formed after $5 \mathrm{~min}$ of saliva contact) differed from that to a 'matured' pellicle (formed after $2 \mathrm{~h}$ of saliva contact) [10]. Furthermore, it is of interest to note that streptococcal adhesion to uncoated substrata of various surface free energies can be described by a thermodynamical model $[10,12,13]$. Streptococcal adhesion to pellicle-coated substrata was far lower than that to uncoated substrata but nevertheless followed the same tendencies as those for the uncoated substrata [10].

The aim of this study was to determine the amount of $\operatorname{sIgA}$ at the outer pellicle surface during pellicle maturation and its effect on oral streptococcal adhesion. Therefore, sIgA was adsorbed from a single protein (sIgA) solution and from human whole saliva onto human enamel and artificial solid substrata with various surface free energies. The amount of adsorbed SIgA was subsequently quantified by an enzyme linked immunoassay (ELISA). In addition, the adhesion of three oral streptococcal strains to surfaces precoated with sIgA was investigated and compared with the adhesion to surfaces precoated with a salivary pellicle.

\section{MATERIALS AND METHODS}

\section{Saliva and salivary secretory $\operatorname{Ig} A$}

Human whole saliva from ten healthy volunteers from both sexes was collected into ice-chilled cups after stimulation of the salivary flow by chewing Parafilm ${ }^{\circledR}$. After pooling and clarifying by centrifugation at $10000 \mathrm{~g}$ for $20 \mathrm{~min}$ at $4^{\circ} \mathrm{C}, 0.2 \mathrm{M}$ phenylmethylsulphonyl fluoride (PMSF), a protease inhibitor, was added to a final concentration of $1 \mathrm{mM}$ in order to prevent enzymatic protein breakdown. Subsequently the solution was recentrifuged, dialysed overnight at $4^{\circ} \mathrm{C}$ against distilled water, and lyophilized for storage. 


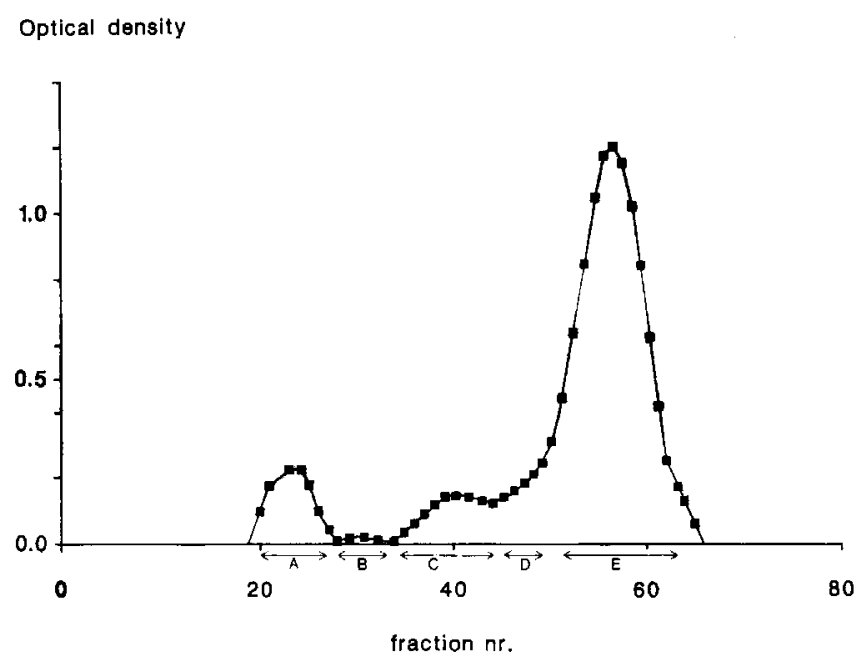

Optical density

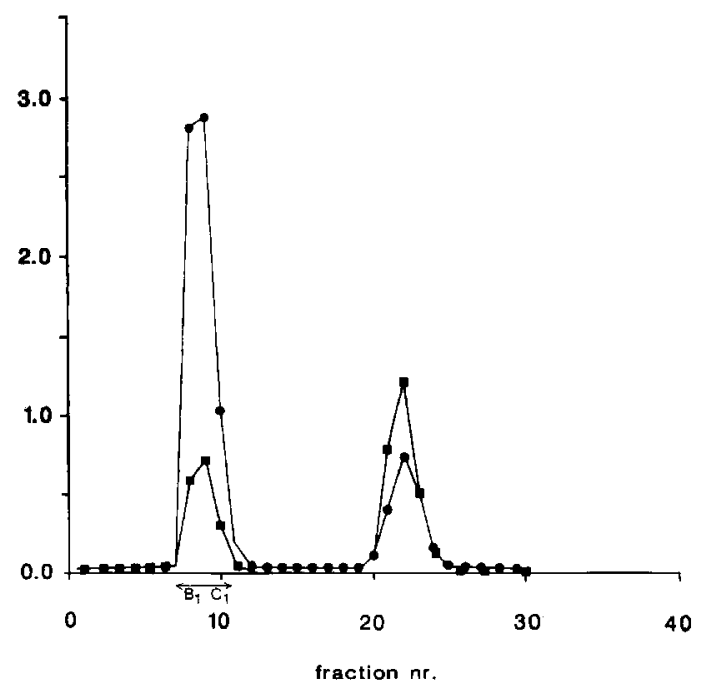

Figure 1. Top: Elution pattern of lyophilized human whole saliva from a Sephadex CL-4B $(2.6 \times 70 \mathrm{~cm})$ column. The SIgA-containing fractions $\mathrm{B}$ and $\mathrm{C}$ were pooled as indicated by the solid bars. Bottom: Elution patterns of lyophilized fractions B and C from a Sephadex G-75 $(1.5 \times 70 \mathrm{~cm})$ column. The sIgA-containing fractions $B_{1}(\square)$ and $C_{1}(O)$ were pooled as indicated by the solid bars.

Part of the lyophilized material was employed for the isolation of SIgA. Therefore, lyophilized saliva $(0.5 \mathrm{~g})$ was dissolved in $10 \mathrm{ml}$ of $0.05 \mathrm{M}$ sodium phosphate buffer (pH 6.8) containing $50 \mathrm{mM} \mathrm{NaCl}$ and $10 \mathrm{mM}$ EDTA. After centrifugation at $10000 \mathrm{~g}$ for $20 \mathrm{~min}$ at $4^{\circ} \mathrm{C}$, the supernatant was applied to a $2.6 \times 70 \mathrm{~cm}$ Sepharose CL-4B column (Pharmacia, Uppsala, Sweden), pre-equilibrated with the same phosphate buffer and eluted at a flow rate of $20 \mathrm{ml} \mathrm{h}^{-1}$ at $4^{\circ} \mathrm{C}$. The absorbances of the $5 \mathrm{ml}$ fractions were monitored at $280 \mathrm{~nm}$.

The IgA-containing fractions $\mathrm{B}$ and $\mathrm{C}$ (see Fig. 1) were dialysed overnight at $4^{\circ} \mathrm{C}$ against distilled water and lyophilized. For further purification pooled 


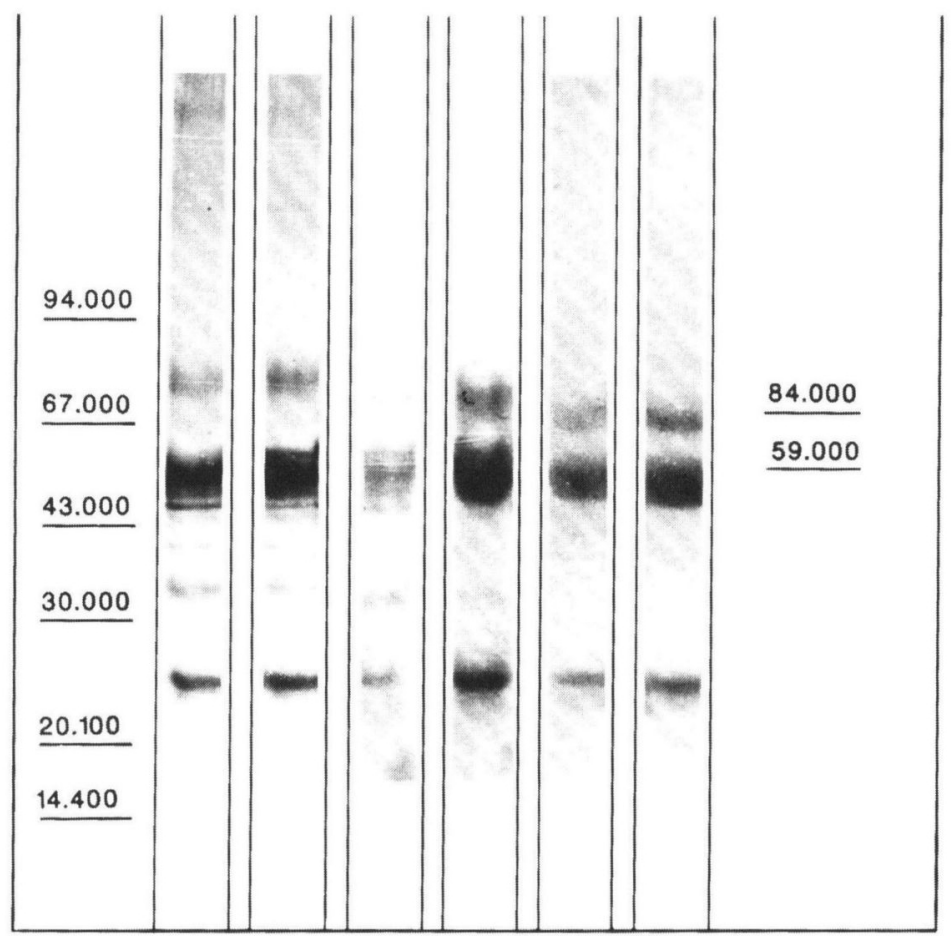

Figure 2. SDS-polyacrylamide gel electrophoresis. Lane A: molecular weight reference sample; lane B: fraction $B$; lane $C$ : fraction $C$; lane $D$ : fraction $B_{1}$; lane $E$; fraction $C_{1}$ (see also Fig. 1); lane $F$; rechromatographed salivary $\operatorname{IgA}$ (fractions $B_{1}$ and $C_{1}$ ); lane $G$ : reference colostrum IgA; and lane $H$; Western immunoblotting pattern of salivary $\operatorname{IgA}$, showing two bands with molecular weights of 84000 and 59000 , which correspond to the $a+$ light chain and the $\alpha$ chain, respectively. The band at 25500 , which was not seen during immunoblotting, represents the light chain of IgA.

lyophilizedfractions $\mathrm{B}$ or $\mathrm{C}(0.5 \mathrm{~g})$ were dissolved in $10 \mathrm{ml} \mathrm{h}^{-1}$ at $4^{\circ} \mathrm{C}$. The fractions containing $\operatorname{IgA}\left(\mathrm{B}_{1}\right.$ and $\mathrm{C}_{1}$, see Fig. 1) were pooled, dialysed against distilled water at $4^{\circ} \mathrm{C}$, and lyophilized. The isolated $\operatorname{sIgA}$ was checked for purity by comparison with reference colostrum secretory IgA (Cappel, Cochranville, USA) in SDS-PAGE and in Western immunoblotting experiments (see Fig. 2), with $\alpha$-chain specific antiIgA (TAGO Inc., Burlington, CA, USA).

Both lyophilized saliva and lyophilized isolated $\operatorname{sigA}$ were dissolved in a potassium phosphate buffer $(2 \mathrm{mM}$ potassium phosphate, $50 \mathrm{mM}$ potassium chloride, and $1 \mathrm{mM}$ calcium chloride, $\mathrm{pH} 6.8$ and surface tension $72.5 \mathrm{~mJ} \mathrm{~m}^{-2}$ ) to a concentration of 2.0 or $0.2 \mathrm{mg} \mathrm{ml}^{-1}$ for lyophilized whole saliva and $0.2 \mathrm{mg} \mathrm{ml}^{-1}$ for sIgA for adsorption studies.

\section{Preparation of enamel and artificial solid substrata}

Human enamel slabs $(3 \times 3 \times 0.4 \mathrm{~mm})$ were cut under running tap-water from freshly extracted human incisors and molars. The labial surfaces were ground planparallel under water with abrasive paper (Siawat, P1200) and polished with a slurry 
of $\mathrm{Al}_{2} \mathrm{O}_{3}$ powder (Buchler Ltd., Evanston, IL, USA) in distilled water to a stylus roughness $R a \leqslant 0.1 \mu \mathrm{m}$.

Previous studies have shown the surface free energy $\gamma_{\mathrm{s}}$ of similarly prepared human enamel to be $88 \mathrm{~mJ} \mathrm{~m}^{-2}$ [14]. Before embedding in a polymethylmethacrylate sample holder $(10 \times 15 \times 10 \mathrm{~mm})$, the polished enamel slabs were cleaned in distilled water in an ultrasonic bath for $15 \mathrm{~min}$ operating at a frequency of $50 \mathrm{~Hz}$.

The following three artificial solid substrata with widely different $\gamma_{\mathrm{s}}$ values were also used: fluoroethylenepropylene co-polymer (FEP Teflon; Fluorplast, Raamsdonkveer, The Netherlands), $\gamma_{s}=20 \mathrm{ml} \mathrm{m}^{-2}$; cellulose acetate (CA; Hawe Néos Dental, Gentilino, Switzerland), $\gamma_{\mathrm{s}}=50 \mathrm{~mJ} \mathrm{~m}^{-2}$; and glass (microscopic slides, Menzel, F.R.G.) $\gamma_{s}=109 \mathrm{~mJ} \mathrm{~m}^{-2}$. Because the artificial solid substrata did not pose the same dimensional limitations as the enamel specimens, rectangles of $10 \times 15 \times 1.0 \mathrm{~mm}$ could be used for the experiments without embedding in a sample holder. The artificial solid substrata were extensively cleaned before the adhesion experiments by rinsing with a $1 \%$ sodium dodecyl sulphate solution for $24 \mathrm{~h}$, followed by rinsing with $0.1 \mathrm{M} \mathrm{HCl}$ for $1 \mathrm{~h}$ and finally by rinsing three times for 1 min with distilled water.

\section{Bacterial strains}

Three strains of oral streptococci with known and widely different surface free energies $\gamma_{\mathrm{b}}$, were selected for this study and included Streptococcus mutans NS $\left(\gamma_{\mathrm{b}}=117 \mathrm{~mJ} \mathrm{~m}^{-2}\right), \quad S$. sanguis $12 \quad\left(\gamma_{\mathrm{b}}=107 \mathrm{~mJ} \mathrm{~m}^{-2}\right)$, and $S$. mitis BMS $\left(\gamma_{\mathrm{b}}=38 \mathrm{~mJ} \mathrm{~m}^{-2}\right)$ [15]. All strains were originally isolated from the human oral cavity and stored at $-20^{\circ} \mathrm{C}$ in Todd Hewitt broth (Oxoid, Basingstoke, UK) containing 7\% (v/v) dimethyl sulphoxide (DMSO). The bacteria were grown from the frozen state in Todd Hewitt broth overnight at $37^{\circ} \mathrm{C}$. This culture was used to inoculate a second culture of Todd Hewitt broth containing $0.5 \%(\mathrm{w} / \mathrm{v})$ glucose for $16 \mathrm{~h}$ at $27^{\circ} \mathrm{C}$ and then harvested by centrifugation. For the adhesion studies the bacteria were washed three times in potassium phosphate buffer and finally suspended in buffer.

\section{Protein adsorption and streptococcal adhesion}

Protein adsorption and bacterial adhesion experiments were both carried out in a previously described flow cell system [12] in order to minimize the passages of a given substratum through liquid-air interfaces, which can give rise to severe artefacts both in protein adsorption and in bacterial adhesion. The cleaned slabs of human enamel, FEP Teflon, cellulose acetate, and glass were vertically positioned in the flow cells and air was purged from the system by flowing with buffer. Then the slabs were exposed for various time intervals to a continuous pulse-free flow of salivary proteins at a moderate shear rate of $21 \mathrm{~s}^{-1}$.

For experiments in which the amount of $\operatorname{sig} \mathrm{A}$ adsorbed was to be quantitated, the slabs were removed after rinsing with buffer in the flow cell system also at a shear rate of $21 \mathrm{~s}^{-1}$ ( $2 \mathrm{~min}$ ) and carefully blotted dry.

The amount of adsorbed sIgA at the outer surface was quantitated with an ELISA technique described later in this paper. The curves representing the amount of sIgA 
adsorbed from a single protein $\operatorname{sigA}$ solution at time $t, \Gamma(t)$, versus the flow time, $t$, were fitted with an iterative least-squares method yielding $j_{0, \mathrm{p}}$ and $\tau_{\mathrm{p}}$ according to

$$
\Gamma(t)=j_{0, \mathrm{p}} \tau_{\mathrm{p}}\left(1-\exp \left(-t / \tau_{\mathrm{p}}\right)\right),
$$

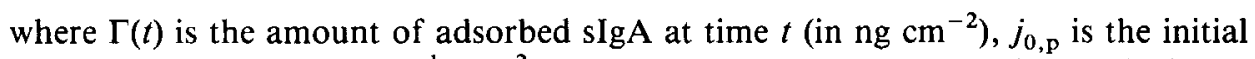
adsorption rate (in $\mathrm{ng} \min ^{-1} \mathrm{~cm}^{-2}$ ), $\tau_{\mathrm{p}}$ is the relaxation time (in min), and $t$ is the flow time (in min).

According to Eqn. (1a), the amount of $\operatorname{sIgA}$ adsorbed at the stationary state $\left(\Gamma_{\mathrm{s}}\right)$ can be calculated from

$$
\Gamma_{s}=j_{0, p} \tau_{\mathrm{p}}
$$

For experiments in which streptococcal adhesion to protein-coated substrata was to be studied, the flow cell system was switched from the protein solution to a bacterial suspension. The protein-coated slabs were exposed to a bacterial suspension without liquid-air passages of the samples for various time intervals $(1<t<60 \mathrm{~min})$, again at the same moderate shear rate of $21 \mathrm{~s}^{-1}$. Rinsing (1 min) and fixation [ $22 \mathrm{~min}$ with $2 \%(\mathrm{v} / \mathrm{v})$ glutardialdehyde in potassium phosphate buffer] were also performed in the flow cell system at identical shear rates to these during adsorption and adhesion. Then the slabs were removed, air-dried, and stained with $5 \%$ crystal violet. The number of attached bacteria was determined with a light microscope by counting ten squares of $1000 \mu \mathrm{m}^{2}$ each in the central part of the substratum.

Analogous to Eqn. (1a), the curves representing the number of adhering bacteria versus the flow time were fitted to

$$
n_{\mathrm{b}}(t)=j_{0, \mathrm{~b}} \tau_{\mathrm{b}}\left(1-\exp \left(-t / \tau_{\mathrm{b}}\right)\right),
$$

where $n_{\mathrm{b}}(t)$ is the number of adhering bacteria at time $t$ (in $\mathrm{cm}^{-2}$ ), $j_{0, \mathrm{~b}}$ is the initial deposition rate (in $\min ^{-1} \mathrm{~cm}^{-2}$ ), $\tau_{\mathrm{b}}$ is the relaxation time (in $\mathrm{min}$ ), and $t$ is the flow time (in $\mathrm{min}$ ).

Similar to Eqn. (2a), the number of bacteria adhering in a stationary state to a given substratum was calculated from

$$
n_{\mathrm{s}}=j_{0, \mathrm{~b}} \tau_{\mathrm{b}}
$$

\section{Quantification of adsorbed $\operatorname{SIg} A$ (ELISA)}

The immunological reaction between horse-radish peroxidase (HRP) conjugated anti-IgA and $\operatorname{IgA}$ was used for the detection and quantification of adsorbed $\operatorname{SIgA}$. The quantification was performed by an enzymatic reaction of the HRP of conjugated anti-IgA with hydrogen peroxide in a buffered ortho-diphenyldiamine (OPD) solution. The subsequent colour change of the OPD in solution is proportional to the amount of adsorbed SIgA [16].

Calibration curves were constructed by adsorbing known amounts of $\operatorname{sigA}(0,20$, $50,100,200,300,400,500,750$, and $1000 \mathrm{ng}$ ) from $1.5 \mathrm{ml}$ of potassium phosphate buffer to disposable polystyrene cuvettes (Lab Center, Breda, The Netherlands). After incubations for $16 \mathrm{~h}$ at room temperature, the supernatants were removed and the cuvettes were washed extensively with potassium phosphate buffer. Then the cuvettes were incubated for $45 \mathrm{~min}$ at $37^{\circ} \mathrm{C}$ with $1.5 \mathrm{ml}$ of $1: 1000$ diluted HRP conjugated anti-IgA (TAGO Inc., Burlington, CA, USA) in buffer $(0.01 \mathrm{M}$ Tris- $\mathrm{HCl}$, 


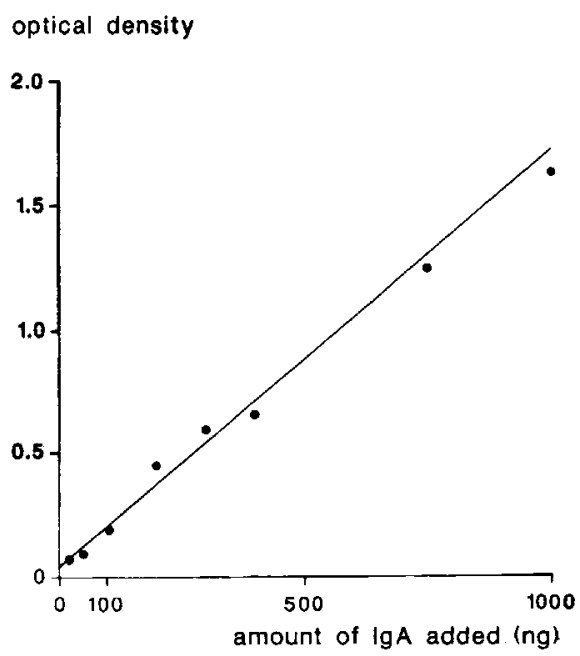

Figure 3. Linear regression line for optical densities vs. the amounts of $\operatorname{sigA}$ added and adsorbed to cuvettes (coefficient of correlation $r=0.995$ ).

$0.2 \mathrm{M} \mathrm{NaCl}, 0.05 \%$ Tween, $1 \% \mathrm{BSA}, \mathrm{pH} 8.0$ ). Thereafter the cuvettes were washed three times with rinsing buffer $(0.01 \mathrm{M}$ Tris- $\mathrm{HCl}, 0.15 \mathrm{M} \mathrm{NaCl}, 0.05 \%$ Tween, pH 8.0). Finally, $1.5 \mathrm{ml}$ of phosphate-buffered OPD solution (Sigma Chemical) containing $0.05 \mathrm{M}$ sodium phosphate, $0.02 \% \mathrm{OPD}$, and $0.15 \% \mathrm{H}_{2} \mathrm{O}_{2}$ was added and after $30 \mathrm{~min}$ incubation at room temperature in the dark the reaction was stopped with $0.1 \mathrm{ml}$ at $0.05 \mathrm{M} \mathrm{H}_{2} \mathrm{SO}_{4}$. The optical densities (OD) of $0.3 \mathrm{ml}$ of the solutions were measured at $492 \mathrm{~nm}$ using a multiscan EIA reader (Flow Reader Amstelstadt, Amsterdam, The Netherlands) with a precision of $0.5 \%$, yielding the calibration curve shown in Fig. 3. This curve could be fitted by linear regression according to

$$
\begin{aligned}
\mathrm{OD}= & 1.67 \times 10^{-3} \times \text { amount of sIgA added }(\mathrm{ng})+0.040 \\
& \text { (linear correlation coefficient } t=0.995)
\end{aligned}
$$

The supernatants of the solutions used for the preparation of the calibration curve were found to be essentially free of $\operatorname{slgA}$, as checked by a conventional ELISA, indicating that all the sIgA added had adsorbed from the solution to the polystyrene cuvettes.

In order to quantify the unknown amounts of $\operatorname{sIgA}$ adsorbed to the various artificial solid substrata, the slabs with adsorbed sIgA were put in clean polystyrene cuvettes and treated as described above, starting with the incubation with $1.5 \mathrm{ml}$ conjugated anti-IgA. Subsequently the optical densities could be transformed into surface concentrations using the calibration curve shown in Fig. 3.

Owing to the dimensional limitation of the available enamel samples, the above procedure, including calibration, was carried out in microtiter plates for the quantification of $\operatorname{sIgA}$ adsorbed onto enamel. Also for this reason, no adsorption experiments were done on enamel with diluted saliva solutions. 
(a)

$r(i) \operatorname{lng} . \mathrm{cm}^{-2}$

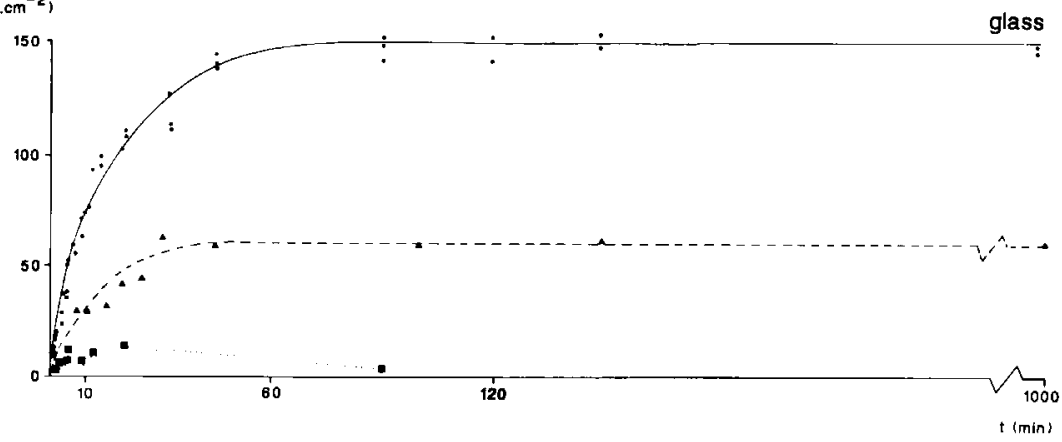

(b) $\Gamma$ (t) $(\mathrm{ng} \cdot \mathrm{cm} \cdot \mathbf{2})$

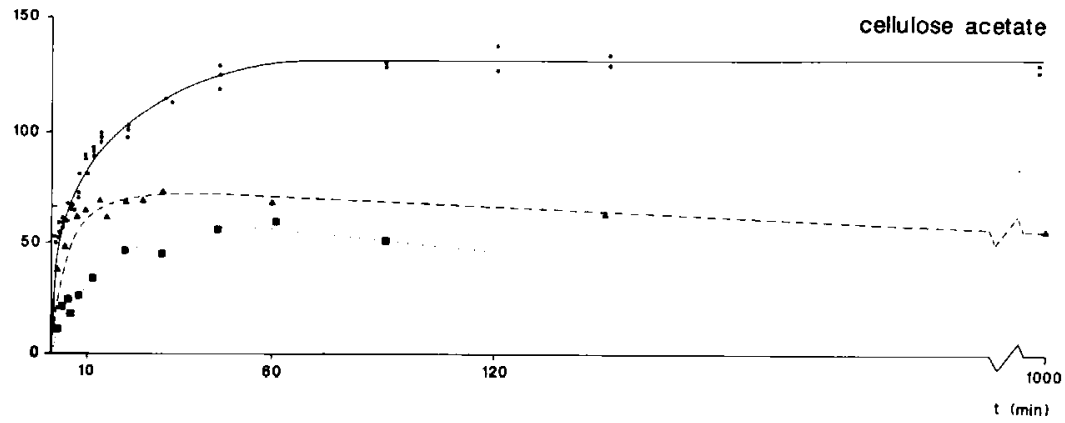

(c)

rit) ing.cm $\mathrm{m}^{-2}$,

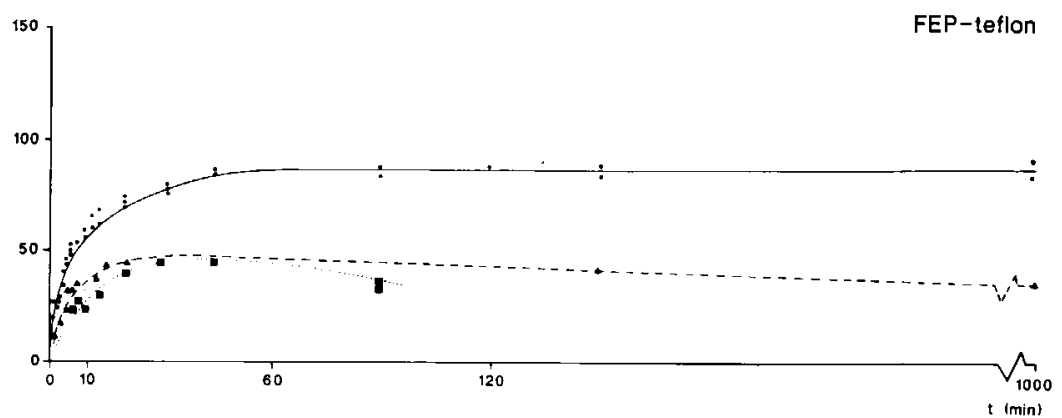

Figure 4. sIgA adsorption, $\Gamma$, from a sIgA solution and human whole saliva onto glass (a), cellulose acetate (b), and FEP Teflon (c) as a function of the adsorption time $t$. (- - ) sIgA solution with a concentration of $0.2 \mathrm{mg} \mathrm{ml}^{-1}$ lyophilized $\operatorname{sigA}$; (- - - - ) human whole saliva with a protein concentration of $2 \mathrm{mg} \mathrm{ml}^{-1} ;(\cdot \cdot \cdots)$ human whole saliva with a protein concentration of $0.2 \mathrm{mg} \mathrm{ml}^{-1}$.

\section{RESULTS}

\section{Protein adsorption}

Figure 4 shows the amounts of $\operatorname{sIgA}$ adsorbed onto the various artificial substrata from reconstituted human saliva with concentrations of 2 and $0.2 \mathrm{mg} \mathrm{ml}^{-1}$ lyophilized whole saliva and purified human salivary $\operatorname{sigA}$ with a concentration of $0.2 \mathrm{mg} \mathrm{ml}^{-1}$ as a function of the adsorption time. The amount of $\operatorname{sigA}$ adsorbed 
Table 1.

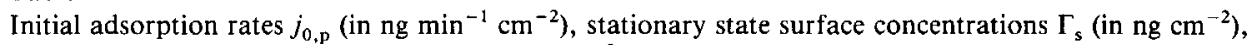
and maximal surface concentration $\Gamma_{\mathrm{m}}$ (in $\mathrm{ng} \mathrm{\textrm {cm } ^ { - 2 }}$ ), of adsorbed sIgA from a single protein component (sIgA) solution, human whole saliva, and diluted saliva to various artificial solid substrata and human enamel $^{a}$

\begin{tabular}{|c|c|c|c|c|c|c|c|c|}
\hline \multirow[b]{2}{*}{ Substratum } & \multicolumn{2}{|c|}{$\begin{array}{c}\operatorname{sIgA} \\
\left(0.2 \mathrm{mg} \mathrm{ml}^{-1}\right)\end{array}$} & \multicolumn{3}{|c|}{$\begin{array}{l}\text { Whole saliva } \\
\left(2.0 \mathrm{mg} \mathrm{ml}^{-1}\right)\end{array}$} & \multicolumn{3}{|c|}{$\begin{array}{l}\text { Diluted Saliva } \\
\left(0.2 \mathrm{mg} \mathrm{m}^{-1}\right)\end{array}$} \\
\hline & $j_{0, \mathrm{p}}$ & $\Gamma_{s}$ & $j_{0, \mathrm{p}}$ & $\Gamma_{s}$ & $\Gamma_{\mathrm{m}}$ & $j_{0, \mathrm{p}}$ & $\Gamma_{s}$ & $\Gamma_{\mathrm{m}}$ \\
\hline FEP & 8.3 & 90 & 9.4 & $-{ }^{b}$ & 47 & 4.8 & $-b$ & 47 \\
\hline $\mathrm{CA}$ & 10.8 & 132 & 14.3 & $-{ }^{b}$ & 73 & 4.2 & $-{ }^{b}$ & 57 \\
\hline Glass & 10 & 153 & 5 & $-{ }^{b}$ & 65 & 1.3 & $-{ }^{b}$ & 12 \\
\hline Enamel & $-{ }^{c}$ & 60 & $-{ }^{c}$ & $-b$ & 28 & $-d$ & $-^{d}$ & $-d$ \\
\hline
\end{tabular}

${ }^{a}$ All experiments were done in triplicate, yielding an average intra-assay $\operatorname{SD}(n=3)$ in $j_{0, \mathrm{p}}$ and $\Gamma_{\mathrm{s}}$ and $\Gamma_{\mathrm{m}}$ of $15 \%$.

${ }^{b}$ Owing to the existence of a maximum surface concentration, no stationary state surface concentration could be determined.

${ }^{c}$ Owing to the low surface concentrations, the initial adsorption rates were not calculated.

${ }^{d}$ The sensitivity of the ELISA technique did not allow quantification of the amount of $\operatorname{sigA}$ on small dental enamel samples from diluted saliva.

from a single protein solution could be fitted to Eqn. (1a), yielding the initial adsorption rate $\left(j_{0, \mathrm{p}}\right)$ and the stationary state surface concentrations, which are summarized in Table 1. However, sIgA adsorption from reconstituted human whole saliva did not follow Eqn. (1a); after an initially linear increase, a maximum surface concentration was reached after approximately $1 \mathrm{~h}$ followed by a steady decrease in the surface concentration. These maximal surface concentrations $\Gamma_{\mathrm{m}}$ are also presented in Table 1.

In contrast to the situation with artificial solid substrata, sIgA adsorption onto human enamel from both a purified SIgA solution and from reconstituted human whole saliva obeyed Eqn. (1a) and no apparent maximum coverage was observed, as can be seen in Fig. 5. The characteristics of sIgA adsorption on enamel are also summarized in Table 1.

(t) ing. $\mathrm{cm}^{-2}$ )

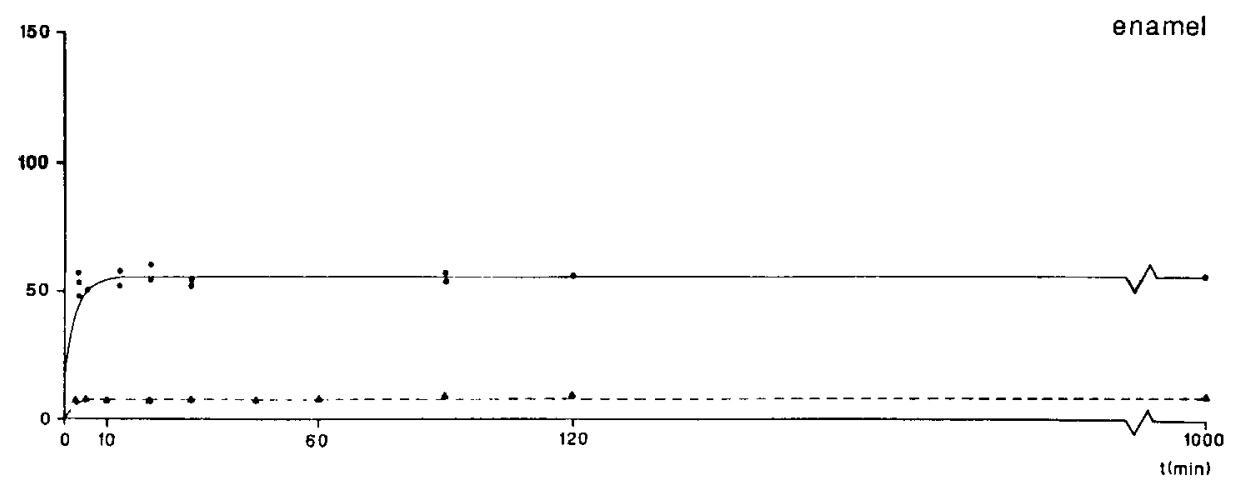

Figure 5. $\operatorname{sigA}$ adsorption, $\Gamma$, from a $\operatorname{sg} A$ solution and human whole saliva onto enamel as a function of the adsorption time $t$. (- - ) sIgA solution with a concentration of $0.2 \mathrm{mg} \mathrm{ml}^{-1}$ lyophilized $\operatorname{sIgA}$; (- - - -) human whole saliva with a protein concentration of $2 \mathrm{mg} \mathrm{ml}^{-1}$. 
Table 2.

The numbers of oral streptococci $\left(\times 10^{6} \mathrm{~cm}^{-2}\right)$ adhering in the stationary state, $n_{s}$, to various artificial solid substrata and enamel before and after exposure for $120 \mathrm{~min}$ to a purified $\operatorname{sIgA}\left(0.2 \mathrm{mg} \mathrm{ml}^{-1}\right.$ solution and after exposure to human whole saliva $\left(2.0 \mathrm{mg} \mathrm{ml}^{-1}\right)$ for 5 and $120 \mathrm{~min}^{a}$.

\begin{tabular}{|c|c|c|c|c|c|}
\hline \multicolumn{2}{|c|}{ Substratum/strain } & \multirow{2}{*}{$\frac{\text { Uncoated }^{b}}{1.5}$} & \multirow{2}{*}{$\frac{\begin{array}{c}120 \mathrm{~min} \\
\mathrm{sIgA}\end{array}}{0.4}$} & \multirow{2}{*}{$\begin{array}{c}\begin{array}{c}5 \mathrm{~min} \\
\text { saliva }^{c}\end{array} \\
0.6\end{array}$} & \multirow{2}{*}{$\frac{\begin{array}{c}120 \mathrm{~min} \\
\text { saliva }^{c}\end{array}}{0.4}$} \\
\hline FEP/ & S. mitis BMS & & & & \\
\hline & S. sanguis 12 & 3.3 & 0.7 & 1.1 & 0.9 \\
\hline & S. mutans NS & 3.6 & 0.5 & 0.9 & 1.5 \\
\hline \multirow[t]{3}{*}{$\mathrm{CA} /$} & S. mitis BMS & 1.5 & 0.3 & 0.5 & 0.3 \\
\hline & S. sanguis 12 & 6.0 & 0.9 & 2.2 & 0.9 \\
\hline & S. mutans NS & 5.7 & 0.5 & 1.1 & 1.6 \\
\hline \multirow[t]{3}{*}{ Glass/ } & S. mitis BMS & 1.0 & 0.2 & 0.5 & 0.2 \\
\hline & S. sanguis 12 & 7.3 & 0.6 & 1.7 & 0.9 \\
\hline & S. mutans NS & 17.0 & 0.6 & 1.4 & 1.5 \\
\hline \multicolumn{2}{|c|}{ Enamel/S. mitis BMS } & 0.7 & 0.4 & 0.5 & 0.6 \\
\hline \multicolumn{2}{|c|}{ S. sanguis 12} & 4.1 & 0.8 & 1.9 & 0.7 \\
\hline & S. mutans NS & 13.8 & 0.5 & 1.3 & 1.9 \\
\hline
\end{tabular}

${ }^{a}$ The inter-assay coefficients of variation for the number of bacteria adhering at the stationary state varied for uncoated substrata from 10 to $15 \%$, whereas they varied for the coated substrata from 20 to $50 \%$.

${ }^{b}$ Data taken from ref. [12].

${ }^{c}$ Data taken from ref. [10].

\section{Streptococcal adhesion}

Table 2 summarizes the numbers of oral streptococci adhering in the stationary state, $n_{\mathrm{s}}$, to various artificial solid substrata in the absence and presence of various protein coatings. From Table 2 it can be seen that precoating of the surfaces with purified $\operatorname{sIgA}$ from human whole saliva as well as with human whole saliva significantly reduces the adhesion of all strains.

\section{DISCUSSION}

The ELISA technique described in this paper enabled the quantification of adsorbed sIgA on artificial solid substrata as well as on human enamel surfaces. In addition, this technique could be used to study the competitive adsorption characteristics of sIgA from saliva. At this stage it must be emphasized that this technique cannot be used for the quantification of sIgA adsorbed in multilayers, because only the outer layer of adsorbed sIgA can bind HRP conjugated anti-IgA and thus be determined. Although this can be considered as a disadvantage, it is most relevant when studying protein adsorption in relation to bacterial and cellular adhesion, as these bioparticles interact primarily with the outermost adsorbed protein layer.

\section{sIg $A$ adsorption}

The results presented in Table 1 suggest that sIgA adsorption is related to the surface free energy of the artificial solid substrata, as is illustrated graphically in Fig. 6. The data point for enamel in Fig. 6 shows that there is less sIgA adsorbed on enamel than 


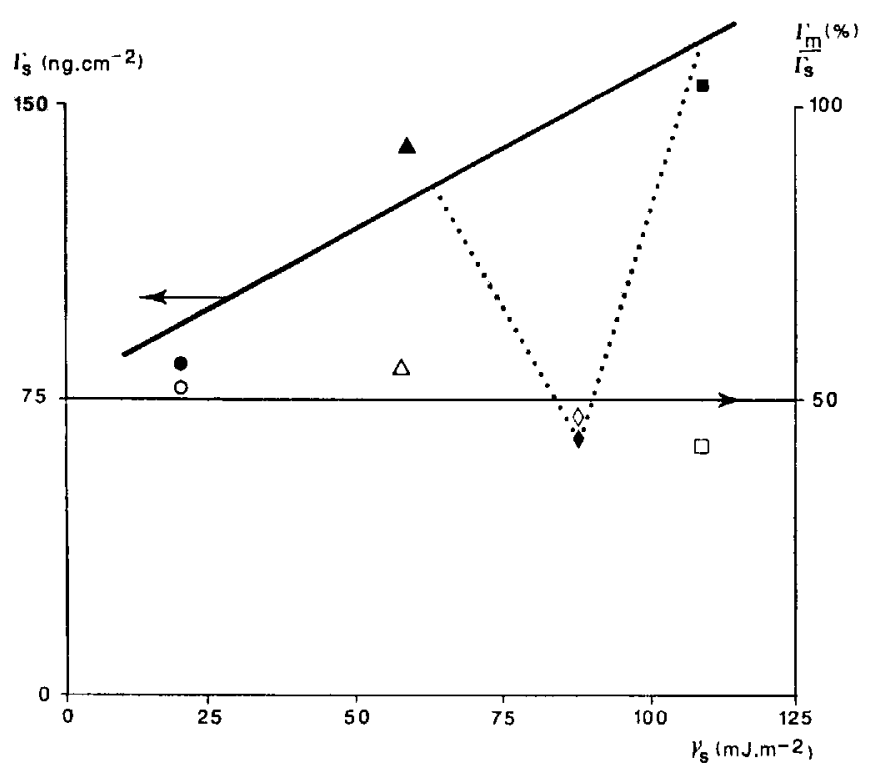

Figure 6. SIgA adsorption onto materials with different surface free energies. ( $\rightarrow$ Adsorbed at the stationary state, $\Gamma_{s}$, from a sIgA solution onto FEP Teflon $(\boldsymbol{O})$, cellulose acetate $(\boldsymbol{\Delta})$, glass $(\boldsymbol{\square})$, and enamel $(\bullet)$ as a function of the surface free energy, $\gamma_{s},(\cdots)$ The ratio $\Gamma_{m} / \Gamma_{s} \times 100 \%$ for FEP Teflon (O), CA $(\triangle)$, glass $(\square)$, and enamel $(\diamond)$ as a function of the surface free energy $\left(\gamma_{s}\right)$.

expected on the basis of the findings for the artificial solid substrata. This can probably be explained by considering the complex structure of enamel, which consists of hydroxyapatite prisms interconnected by an organic matrix. Proteins leaching out of the organic matrix adsorb immediately on the prism surface, thereby leaving less surface available for sIgA [17]. It is also interesting to consider the ratio $\Gamma_{\mathrm{m}} / \Gamma_{\mathrm{s}}$ as a function of the surface free energy, in which $\Gamma_{m}$ is the maximum amount of sIgA adsorbed from saliva and $\Gamma_{s}$ is the stationary state surface concentration of sIgA adsorbed from a purified sIgA.

This ratio, also shown in Fig. 6, has an almost constant value for both the artificial solid substrata and the enamel surface. This percentage (approximately $50 \%$ ) is significantly higher than the percentage sIgA in saliva (approximately 10\%), which indicates that all surfaces preferentially adsorb sIgA from saliva.

On the high surface free energy substrata for the concentrations of 2.0 and $0.2 \mathrm{mg} \mathrm{ml}^{-1}$ saliva, a clear concentration dependence is observed for selective sIgA adsorption from saliva; for the low surface free energy substratum FEP Teflon this concentration dependence is absent. Hence, it was concluded that sIgA adsorbs essentially irreversibly to FEP Teflon. However, a maximum in the concentration of sIgA at the outer pellicle surface during pellicle ripening was evident only for FEP Teflon. Therefore, the existence of this maximum in surface concentration is most likely due to screening of readily adsorbed sIgA by other proteins, rather than to displacement, which requires a more reversible binding.

A 'Vroman-like' effect has not yet been described in the literature for pellicle formation on an enamel surface $[6,8,9,18-21]$. Although the results of this study do not present direct evidence for such a screening or displacement process for salivary protein adsorption on enamel, this phenomenon was observed on FEP Teflon. 
Thus, a 'Vroman' effect may exist for pellicle formation on enamel too, but more research including other proteins is required to establish the existence of this phenomenon.

\section{Thermodynamic analysis of streptococcal adhesion}

The adhesion of bacteria to solid substrata involves specific interactions between complementary surface components [22] and physico-chemical surface characteristics such as charge, hydrophobicity [23-25], and surface free energies [26-29]. Using a thermodynamic approach in which electrical charge interactions are neglected, adhesion can be predicted on the basis of an interfacial free energy balance. According to Absolom et al. [27] and Busscher et al. [26], adhesion will be energetically favourable if

$$
\Delta F_{\mathrm{adh}}=\gamma_{\mathrm{sb}}-\gamma_{\mathrm{sl}}-\gamma_{\mathrm{bl}}<0,
$$

where $\Delta F_{\text {adh }}$ is the interfacial free energy of adhesion, $\gamma_{\mathrm{ab}}$ is the solid-bacterium interfacial free energy, $\gamma_{\mathrm{sl}}$ is the solid-liquid interfacial free energy, and $\gamma_{\mathrm{bl}}$ is the bacterium-liquid interfacial free energy.

Adhesion will be energetically unfavourable if

$$
\Delta F_{\text {adh }}>0 \text {. }
$$

The interfacial free energies can be calculated from an approach based on separating surface free energies into a dispersion and a polar component denoting van der Waals interactions and the capacity to donate or accept hydrogen ions, respectively [30]. According to the geometric mean equation, the interfacial free energy between any two surfaces, 1 and 2, can be expressed using the dispersion and polar components by

$$
\gamma_{12}=\gamma_{1}+\gamma_{2}-2\left(\gamma_{1}^{d} \gamma_{2}^{d}\right)^{1 / 2}-2\left(\gamma_{1}^{p} \gamma_{2}^{p}\right)^{1 / 2},
$$

where $\gamma_{12}$ is the interfacial free energy between surfaces 1 and $2 ; \gamma_{1}$ and $\gamma_{2}$ are the surface free energies of surfaces 1 and 2 respectively; $\gamma_{1}^{p}$ and $\gamma_{2}^{p}$ denote the polar components of the surface free energies of surfaces 1 and 2 , respectively; and $\gamma_{1}^{d}$ and $\gamma_{2}^{d}$ denote the dispersion components of the surface free energies of surfaces 1 and 2 , respectively.

Recently we have demonstrated that the adhesion of a wide variety of oral streptococcal strains adhering at the stationary state to homogeneous artificial solid substrata as well as to an inhomogeneous enamel surface can be described by the following thermodynamic model:

$$
n_{\mathrm{s}}=a\left(\Delta F_{\mathrm{adh}}-23.1\right)+1.2,
$$

where $n_{\mathrm{s}}$ is the number of bacteria adhering at the stationary state to a solid substratum (in $10^{6} \mathrm{~cm}^{-2}$ ); $\Delta F_{\mathrm{adh}}$ is the interfacial free energy of adhesion (in $\mathrm{mJ} \mathrm{m}{ }^{-2}$ ); and $a$ is a strain-specific microbial factor (in $10^{10} \mathrm{~mJ}^{-1}$ ), which is associated with the absence or presence of fibrillar surface appendages and the capacity of the strain to excrete substances with a tendency to modify the substratum properties.

From Fig. 7, representing the numbers of bacteria adhering at the stationary state to the different uncoated and $\operatorname{sigA-coated~surfaces~as~a~function~of~the~interfacial~}$ 

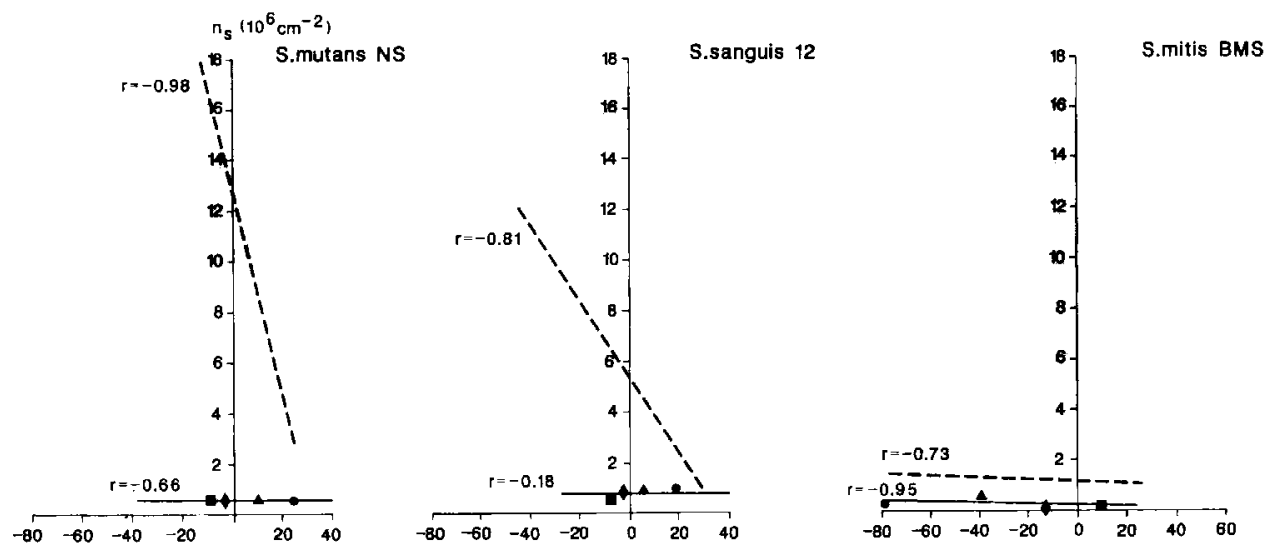

Figure 7. The numbers of bacteria adhering at the stationary state, $n_{\mathrm{s}}$ to glass $(\boldsymbol{\square})$, enamel $(\bullet), \mathrm{CA}(\mathbf{\Delta})$, and FEP Teflon ( $)$ as a function of the interfacial free energy of adhesion, $\Delta F_{\text {adh }}$, after $2 \mathrm{~h}$ exposure to a sIgA solution $\left(0.2 \mathrm{mg} \mathrm{ml}^{-1}\right)$. The numbers of bacteria adhering at the stationary state to clean substrata are indicated by a dotted line. Data taken from regs $[10,12]$.

free energy of adhesion, it is clear that the sensitivity of $S$. mutans NS, S. sanguis 12 , and $S$. mitis BMS to $\Delta F_{\text {adh }}$, as represented by the ' $a$ ' factor, is much lower for sIgA-coated substrata than for the uncoated substrata. However, the persistent tendency towards small negative slopes, albeit with admittedly low coefficients of correlation, suggests that the substratum properties are, in part, transferred to the bacterium-protein interface.

\section{sIgA adsorption and oral streptococcal adhesion}

sIgA is known to be a regular component of the acquired pellicle which can interfere with the adhesion of bacteria to solid surfaces [11]. We have determined the percentage reduction in adhesion for the three oral streptococcal strains, setting the adhesion to bare uncoated substrata to $100 \%$. The percentage adhesion is plotted in Fig. 8 as a function of sIgA exposed at the outer pellicle surface. For $S$. mitis BMS and
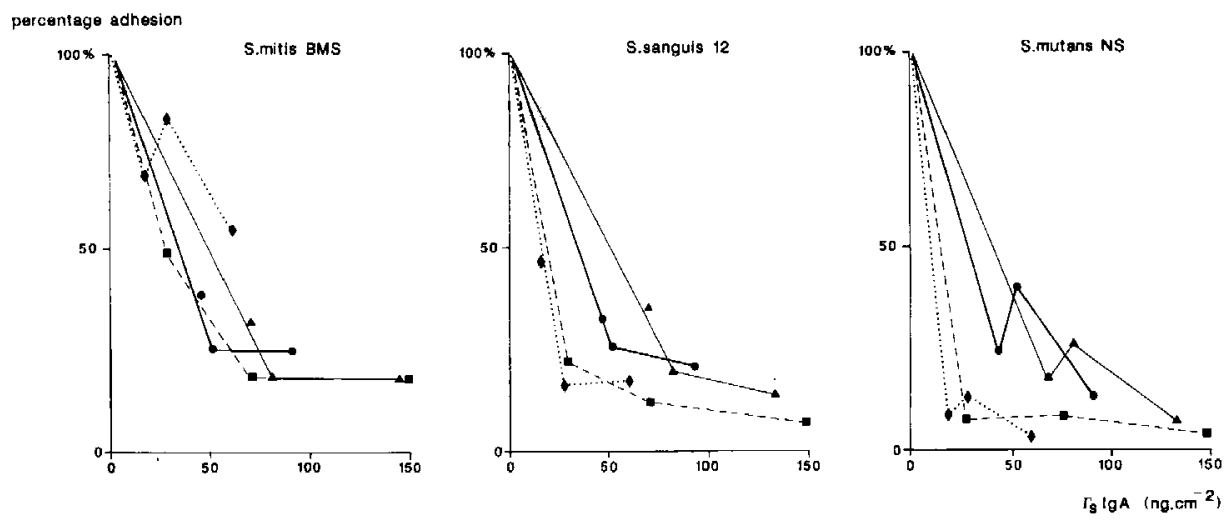

Figure 8. The percentage of adhesion of $S$. mitis BMS, S. sanguis 12, and S. mutans NS to FEP Teflon $(\mathbf{O})$, cellulose acetate $(\boldsymbol{\Delta})$, glass $(\boldsymbol{\square})$, and enamel ( ) (taking the adhesion to clean substrata as $100 \%$ ) as a function of the amount of adsorbed $\operatorname{SIgA}$ at the outer pellicle surface adsorbed during 5 and $120 \mathrm{~min}$. 
particularly for $S$. sanguis 12 , the percentage adhesion decreases gradually with increasing sIgA exposure, but irregularly for $S$. mutans NS. Speculatively, this could suggest that for $S$. mitis and $S$. sanguis this reduction is mainly due to a non-specific protein effect. In the case of $S$. mutans, a specific protein effect could be involved next to the non-specific protein effect, since for this strain the effect of sIgA seems to depend more on the substratum to which it is adsorbed. This can be due to the conformational state in which a protein is adsorbed and which is expected to change more on hydrophobic surfaces such as FEP Teflon than on hydrophilic materials [31], thus exposing different antigenic groups on various solid substrata. These results are partly in contradiction with the results of Kilian et al. [11], who concluded that the decreased adherence of $S$. sanguis was thought to be due to both a specific and a non-specific protein effect. However, the net effect of these specific and non-specific interactions may well be dependent on the titre of the specific antibodies, which can explain the differences between the results of Kilian et al. [11] and the results described in this paper.

\section{Acknowledgement}

We are greatly indebted to Mrs Marjon Schakenraad-Dolfing for the preparation of the manuscript.

\section{REFERENCES}

1. L. Vroman, A. L. Adams, M. Klingsand and G. Fisher, Adv. Chem. Sci. 145, 255 (1975).

2. S. A. Horbett and P. K. Weathersby, J. Biomed. Mater. Res.15, 403 (1981).

3. D. F. Williams, I. N. Askill, R. Smith J. Biomed. Mater. Res. 19, 313 (1985).

4. M. Mogi, B. Y. Hiraoaka, M. Harada, T. Kage, T. Chino, Arch. Oral Biol. 31, 337 (1986).

5. C. A. Saxton, Caries Res. 7, 102 (1973).

6. D. I. Hay, Arch. Oral Biol. 12, 937 (1967).

7. R. J. Gibbons, I. Etherden and W. Peros, Molecular Basis of Oral Microbial Adhesion, pp. 77-84, S. E. Mergenhagen and B. Rosan (eds). Am. Soc. Microbiol. Washington, DC (1985).

8. D. I. Hay and E. C. Moreno, J. Dent. Res. 58, 45 (1979).

9. T. Sönju and G. Rölla, Caries Res. 7, 30 (1973).

10. I. H. Pratt-Terpstra, A. H. Weerkamp, H.J. Busscher, J. Dent. Res. 68, 463 (1989).

11. M. Kilian, K. Roland and J. Mestecky, Infect. Immunol. 31, 942 (1981).

12. I. H. Pratt-Terpstra, A. H. Weerkamp and H. J. Busscher, J. Gen. Microbiol. 133, 3199 (1987).

13. I. H. Pratt-Terpstra, A. H. Weerkamp and H. J. Busscher, J. Colloid Interface Sci. 129, 568 (1988).

14. A. W. J. van Pelt, A. H. Weerkamp, M. H. W. J. C. Uyen, H. J. Busscher, H. P. de Jong and J. Arends, Appl. Environ. Microbiol. 49, 1270 (1985).

15. A. W. J. van Pelt, H. C. van der Mei, H. J. Busscher, J. Arends and A. H. Weerkamp, FEMS Microbiol. Lett. 25, 279 (1984).

16. K. Merritt. C. R. Edwards and S. A. Brown, J. Biomed. Mater. Res. 22, 99 (1988).

17. H. P. de Jong, A. W. J. van Pelt and J. Arends, J. Dent. Res. 611 (1982).

18. D. Ørstavik and F. W. Kraus, J. Oral Pathol. 2, 68 (1973).

19. C. W. Mayhall, Arch. Oral Biol. 15, 1323 (1970).

20. K. H. Eggen and G. Rölla, Scand. J. Dent. Res. 90, 182 (1982).

21. K. H. Eggen and G. Rölla, Cariology Today. Int. Congress, Munich, 1983, pp. 108-111. Karger, Basel (1984).

22. R. J. Gibbons, In: Microbial Adhesion to Surfaces, pp. 351-378, R. C. W. Berkeley, J. M. Lynch, J. Melling, P.R. Rutter and B. Vincent (Eds). Ellis Horwoord, Chichester (1980).

23. M. Rosenberg, D. Gutnick and E. Rosenberg, FEMS Microbiol. Lett. 9, 29 (1980).

24. R. J. Doyle, W. E. Nesbitt and K. J. Taylor, FEMS Microbiol. Lett. 15,1 (1982). 
25. A. H. Weerkamp, H. C. van der Mei, D. P. E. Engelen and C. E. A. de Windt, In: Bacterial Adhesion and Preventative Dentistry, pp. 85-97, J. M. ten Cate, S. A. Leach and J. Arends, (eds). IRL Press, Oxford (1984).

26. H. J. Busscher, A. H. Weerkamp, H. C. van der Mei, A. W. J. van Pelt, H. P. de Jong and J. Arends, Appl. Environ. Microbiol. 48, 980 (1984).

27. D. R. Absolom, F. V. Lamberti, Z. Policova, W. Zingg, C. J. van Oss and A. W. Neumann, Appl. Environ. Microbiol. 46, 90 (1983).

28. M. H. W. J. C. Uyen, H. J. Busscher, A. H. Weerkamp and J. Arends, FEMS Microbiol. Lett. 30, 303 (1985).

29. M. Fletcher and J. H. Pringle, J. Colloid Interface Sci. 104, 5 (1985).

30. C. J. van Oss, R. J. Good and M. K. Chaudhury, Sep. Sci. Technol. 22, 1 (1987).

31. B. Ivarsson and I. Lundström, CRC Lit. Rev. Biocomp. 2, 1 (1986). 